\title{
Shearing Performance of Lime-Reinforced Iron Tailing Powder Based on Energy Dissipation
}

\author{
Ping Jiang $\mathbb{D}^{1},{ }^{1}$ Lingqi Qiu, ${ }^{1}$ Na Li $\mathbb{D},{ }^{1}$ Wei Wang $\mathbb{D},{ }^{1}$ Aizhao Zhou, ${ }^{2}$ and Jingping Xiao ${ }^{3}$ \\ ${ }^{1}$ School of Civil Engineering, Shaoxing University, Shaoxing, Zhejiang 312000, China \\ ${ }^{2}$ Department of Civil and Architecture Engineering, Jiangsu University of Science and Technology, Zhenjiang, Jiangsu 212003, \\ China \\ ${ }^{3}$ Huahui Engineering Design Group Co. Ltd, Shaoxing, Zhejiang 312000, China
}

Correspondence should be addressed to Wei Wang; wangwells@qq.com

Received 15 June 2018; Accepted 10 September 2018; Published 21 October 2018

Guest Editor: Yonggui Chen

Copyright (C) 2018 Ping Jiang et al. This is an open access article distributed under the Creative Commons Attribution License, which permits unrestricted use, distribution, and reproduction in any medium, provided the original work is properly cited.

\begin{abstract}
The resource utilization of iron tailing powder is an effective measure to reduce the risk of tailing stacking. Based on the research findings on lime soil, a method for using lime to strengthen iron tailing powder was proposed. F- $s$ curves and $c$ and $\varphi$ values of iron tailing powder with $0 \%, 2 \%, 4 \%, 8 \%$, and $10 \%$ lime were obtained through direct shear tests. The back propagation (BP) neural network algorithm was used to fit the $F$ - $s$ curve, and the fitting equation that met the accuracy requirement was obtained. Based on the energy dissipation theory, the shear failure energy dissipation of iron tailing powder with different lime doses was achieved in the form of definite integrals under different normal stresses of $100 \mathrm{kPa}, 200 \mathrm{kPa}, 300 \mathrm{kPa}$, and $400 \mathrm{kPa}$, respectively. It was concluded that the addition of lime could increase the shear energy dissipation of iron tailing powder. The shear energy dissipation of iron tailing powder first increased and then decreased with the increase in lime dose. The maximum value was reached with $4 \%$ lime, and the energy dissipation increased linearly with increasing normal stress. In this study, the shear performance of limereinforced iron tailing powder was studied through the direct shear test combined with the energy dissipation theory, providing a theoretical basis for the resource utilization of iron tailing powder.
\end{abstract}

\section{Introduction}

Iron tailing powder is one of the products of iron ore sorting operation. Not only it has an impact on the surrounding environment, the tailing stacking also seriously threatens the lives and property of the people downstream of the reservoir area. Therefore, how to use tailings and turn waste into treasure is a matter of great concern to local governments. By the end of 2017, the total stock of various types of tailings in China reached 16 billion tons, of which iron tailings account for one-third of all tailings. Taking Zhejiang Lizhu Iron Ore as an example, about 200,000 tons of dehydrated tailings are produced each year. More than 20 million tons of tailings accumulate in the existing tailing dam storage yard, and the iron tailings occupy a large proportion of land resources with a risk of dam break.

Many studies were conducted on the resource utilization of iron tailing powder, including concrete fine aggregates [1], wastewater treatment [2], filling materials of composite material [3], recovery of iron ore [4], and use as a road material [5]. The particles with larger particle sizes in Lizhu iron tailings can be used as building materials, bringing economic benefits. However, the tailing particles with a particle size of less than $0.075 \mathrm{~mm}$ are small, nonviscous, nonphysicochemically active, and difficult to utilize and transform. Therefore, certain strategies are needed to increase the degree of resource utilization.

Lime-reinforced soil is a building material with a long history; its mechanical properties have been previously explored. Based on the unconfined compressive strength and splitting strength of lime soil, the Mohr-Coulomb destruction envelope curve of lime soil was investigated by Consoli using lime content and porosity as basic parameters [6]. A series of studies were conducted by Wang, including size effect on cementitious aggregates during curing of calcined soil; thermal conductivity, suction, and microstructural changes 
during curing; and the effect of aggregate size on the compressibility and air permeability of lime-treated fine-grained soils [7-9]. Jha studied the volume change behavior and strength growth mechanism of lime-treated gypseous soil from the perspective of mineralogy and microstructure $[10,11]$. The short-term effects of the physical properties of lime-treated kaolin were studied by Vitale [12]. The aforementioned findings indicated that lime could fill the pores between soil particles to a certain extent and react with the active silica and other components in the soil to improve their mechanical properties.

Therefore, lime soil research findings can be used for reference. The iron tailing powder can be modified with lime to form a new composite soil material, which can be used in practical engineering. Energy dissipation is a commonly used method for studying material failure performance such as the factor of safety (FS) of 3D stepped slopes [13], constitutive model for geotechnical materials [14, 15], soilsweep interaction [16], mechanical behaviors of soil $[17,18]$, and cement soil $[19,20]$. Shearing performance is the most basic mechanical property of geotechnical materials. Therefore, the research findings on lime soil can be used to study the shear properties of lime-reinforced iron tailing powder based on energy dissipation theory.

\section{Physicochemical Properties of Iron Tailing Powder}

The test samples were obtained from Zhejiang Lizhu Iron Ore (Figure 1). The chemical composition, physical properties, and particle composition were tested separately. The test results were as follows.

According to the chemical analysis method of GB/T1762008, the content of $\mathrm{SiO}_{2}$ and $\mathrm{MgO}$ was higher $(41.11 \%$ and $16.7 \%$, resp.). The contents of $\mathrm{SO}_{3}$ and $\mathrm{Na}_{2} \mathrm{O}$ were lower $(0.46 \%$ and $0.29 \%$, resp.). The iron ore tailings contained $10.8 \% \mathrm{Fe}_{2} \mathrm{O}_{3}$. The main chemical composition of iron tailing powder is shown in Table 1.

Loss on ignition, chloride ion, total alkali content, specific gravity, and specific surface area of iron tailing powder were tested. The test results are shown in Table 2.

Since the iron tailing powder contained fine particles after sorting, the particle size analysis of iron tailing powder (less than $45 \mu \mathrm{m}, 45-75 \mu \mathrm{m}, \quad 75-100 \mu \mathrm{m}, 100-150 \mu \mathrm{m}$, and more than $150 \mu \mathrm{m}$ ) was conducted using a Mastersizer2000 laser particle size analyzer. The results are shown in Figure 2.

\section{Direct Shear Test}

Lizhu iron tailing powder has a certain content of $\mathrm{SiO}_{2}$. However, the particle size of iron tailings is less than $45 \mu \mathrm{m}$. Therefore, a method of using lime to strengthen iron tailing powder was proposed to increase the resource utilization of Lizhu iron tailing powder. The shear performance of the material was the basic mechanical index. The direct shear test was used to study the shear properties of lime-reinforced tailing powder.
3.1. Sample Preparation and Testing. The sample was quicklime, and the lime dose was the percentage of the dry mass of lime relative to iron tailing powder. The doses were $0 \%, 2 \%, 4 \%, 8 \%$, and $10 \%$. These percentages were chosen considering both international and China experience with soil-lime mixtures in experimental work [6-9]. In the preparation process, quicklime and iron tailing powders were first stirred for $3 \mathrm{~min}$. Then, $17 \%$ of water was added and stirred for another $3 \mathrm{~min}$. After standing for $24 \mathrm{~h}$, they were put into a ring knife with a diameter of $61.8 \mathrm{~mm}$ and a height of $20 \mathrm{~mm}$. A layer of petroleum jelly was smeared to the interior of the ring knife. The sample was formed by compaction, and the upper and lower surfaces of the sample were leveled. After leaving for $2 \mathrm{~h}$, demolding was performed and the weight of each sample was determined. The weight of the sample should be controlled at $146 \mathrm{~g} \pm 2 \mathrm{~g}$. The samples were wrapped in a natural environment for $24 \mathrm{~h}$ using a plastic wrap (Figure 3 ) and subjected to direct shear test.

The test equipment was a fully automatic quadruple direct shear apparatus (Figure 4) produced by Nanjing TKA Technology Co., Ltd. It could perform direct shear tests under the action of four normal stresses simultaneously, ensure the test accuracy, and improve the test efficiency. The normal stresses were $100 \mathrm{kPa}, 200 \mathrm{kPa}, 300 \mathrm{kPa}$, and $400 \mathrm{kPa}$, and the shear rate was $1 \mathrm{~mm} / \mathrm{min}$. Six shear forces $(F)$ and corresponding shear displacements $(s)$ were recorded every second during the test.

3.2. Test Results and Analysis. Based on the test results, the shear force versus displacement curves of lime-reinforced iron tailings under different normal stresses were plotted, as shown in Figure 5.

The peak force $F_{\max }$ was extracted and the peak shear strength $\tau_{\max }$ was calculated using the $F$-s curve according to Equation (1). The cohesion $c$ and the internal friction angle $\varphi$ of lime-reinforced iron tailings powder with different lime doses were calculated according to the Mohr-Coulomb principle (Equation (2)) and are plotted in Figure 6:

$$
\begin{aligned}
\tau_{\max } & =\frac{F_{\max }}{A}, \\
\tau & =c+\sigma \tan \varphi .
\end{aligned}
$$

Figure 6 shows that the internal friction angle of iron tailing powder increased with increasing lime dose to some extent. When the lime dose increased from $0 \%$ to $8 \%$, the internal friction angle increased from $31.7^{\circ}$ to $34.7^{\circ}$. From $8 \%$ to $10 \%$, the internal friction angle increased obviously from $34.7^{\circ}$ to $42.7^{\circ}$, indicating that the addition of quicklime enhanced the friction force between tailing particles to some extent.

The cohesive force of iron tailing powder with added lime first increased and then decreased with increasing amount of quicklime. When the lime dose increased from $0 \%$ to $8 \%$, the cohesive force increased from $12.3 \mathrm{kPa}$ to $96.5 \mathrm{kPa}$ with obvious growth about seven times. However, when the lime dose increased from $8 \%$ to $10 \%$, the cohesion 


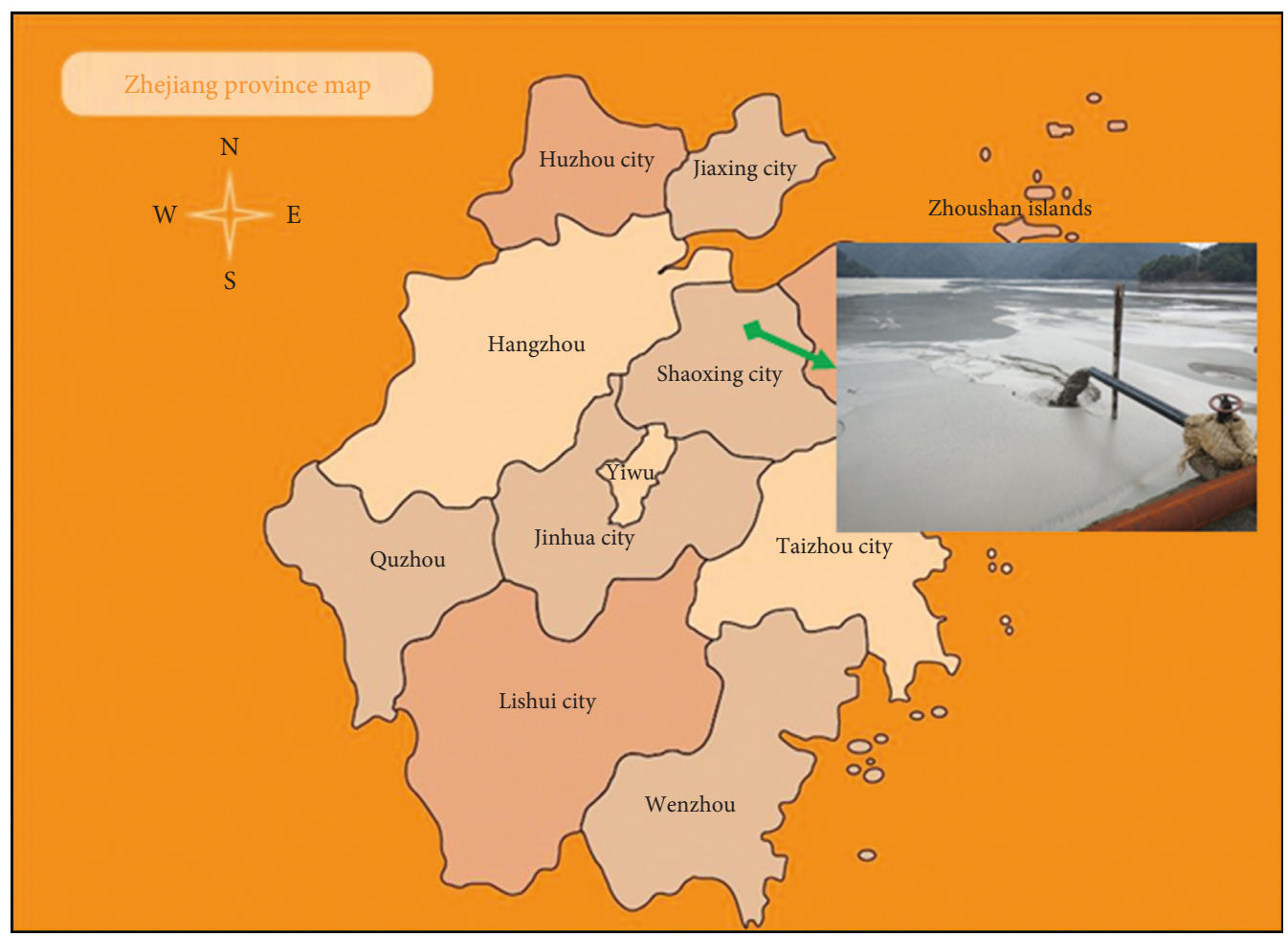

FIgURE 1: The position of Zhejiang Lizhu Iron tailings.

TABle 1: Chemical composition of iron tailings powder.

\begin{tabular}{lcccccccc}
\hline Composition & $\mathrm{SiO}_{2}$ & $\mathrm{Fe}_{2} \mathrm{O}_{3}$ & $\mathrm{Al}_{2} \mathrm{O}_{3}$ & $\mathrm{CaO}$ & $\mathrm{MgO}$ & $\mathrm{SO}_{3}$ & $\mathrm{~K}_{2} \mathrm{O}$ & $\mathrm{Na}_{2} \mathrm{O}$ \\
\hline Mass fraction (\%) & 41.11 & 10.8 & 8.19 & 13.99 & 16.7 & 0.46 & 0.72 & 0.29 \\
\hline
\end{tabular}

TABLe 2: Main physical parameters of iron tailings powder.

\begin{tabular}{lccccc}
\hline Composition & LOI & CI & Total alkali content & Specific gravity & Specific surface area $\left(\mathrm{m}^{2} / \mathrm{kg}\right)$ \\
\hline Parameter & 7.01 & 0.21 & 0.76 & 3.06 & 379
\end{tabular}

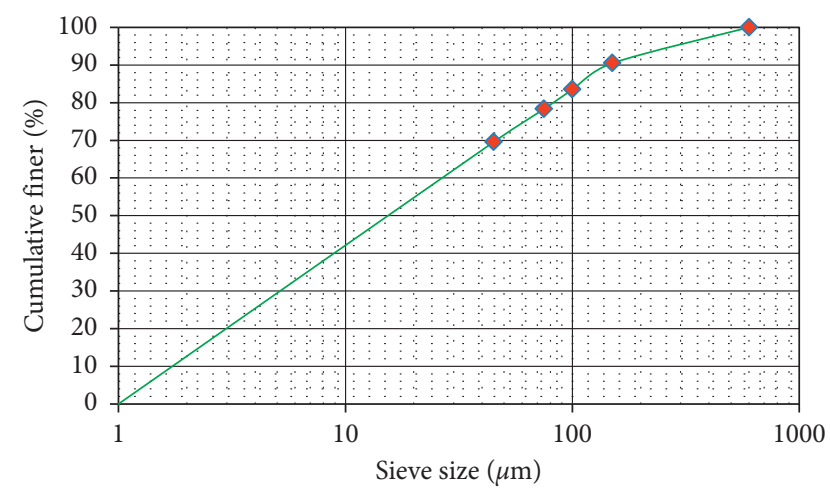

FIgURE 2: Iron tailings powder distribution curve.

decreased from $96.5 \mathrm{kPa}$ to $36.3 \mathrm{kPa}$. It showed that quicklime could improve the cohesion of iron tailing powder when the lime dose increased from $0 \%$ to $8 \%$, but the cohesion decreases when the lime dose increased from $8 \%$ to $10 \%$.

Since the particle size of the quicklime particles was about $1 \mu \mathrm{m}$, and iron tailing powder comprised particles smaller than $45 \mu \mathrm{m}$, the quicklime particles could fill gaps between the iron tailing powder particles to some extent, thereby improving their adhesion. When the lime dose was between $2 \%$ and $8 \%$, the cohesion of lime-reinforced iron tailing powder increased. As quicklime particles were fine and easy to slide, the frictional effect between iron tailing powder particles was not obvious. Therefore, the shear strength of lime-reinforced iron tailings powder increased within a certain range of lime dose. When the amount of quicklime reached $10 \%$, there produces one or several layers of the lime closely and continuously around the outside surface of the iron tailings powder particles, which just like a "lime film" forming around the iron tailing powder particles, decreasing the cohesion of the iron 


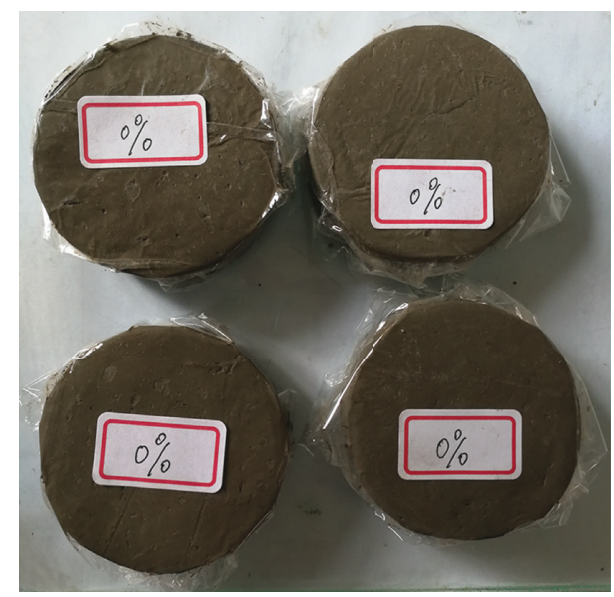

FIgURE 3: Iron ore tailings direct shear sample.

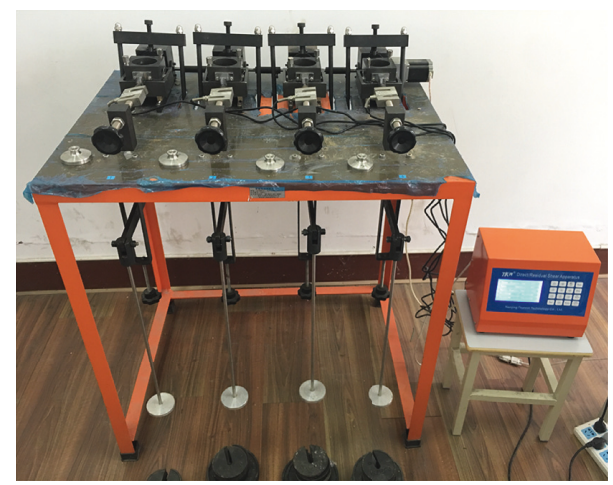

FIGURE 4: Fully automatic quadruple direct shear apparatus.

tailing powder particles and increasing the internal friction angle.

\section{Energy Dissipation}

The direct shear test results of lime-reinforced iron tailing powder indicated that a certain amount of quicklime could improve the cohesion and internal friction of the tailing powder, thereby improving its shear resistance. However, it is difficult to comprehensively evaluate the effect of lime dose on the shear performance of iron tailing powder due to two independent parameters of cohesion and internal friction angle. The failure process of the sample direct shear test is actually an energy-dissipating process. Therefore, the characteristics of the direct shear test indicate that the energy dissipation can be used to characterize the sample failure process. That is, the characteristics of the F-s curve show that the work done by the shear force is the energy dissipation of sample failure. Due to the limited discrete data points obtained during the direct shear test, it is necessary to accurately obtain the $F-s$ function relationship to accurately obtain the energy dissipation by the test sample. BP neural network is a common data-fitting method. A reasonable neural network structure can simulate almost any nonlinear function $[21,22]$. The BP neural network algorithm was used in this study to fit the F-s curve, and then the definite integral method was used to achieve the shear energy dissipation of lime-reinforced iron tailings powder.

4.1. BP Neural Network Curve Fitting. A BP neural network structure with one hidden-layer and two hidden-layer nodes was chosen: input node and output node. Hidden-layer transfer functions are expressed as in Equation (3), output-layer transfer functions as in Equation (4), and BP neural network information transfer as in Equation (5):

$$
\begin{aligned}
& f(v)=\frac{1}{e^{-v}+1}, \\
& f(v)=v, \\
& f(v)=\frac{\omega_{2}}{e^{-\left(\omega_{1} v+b_{1}\right)}+1}+b_{2},
\end{aligned}
$$

where $\omega_{1(2 \times 1)}$ and $b_{1(2 \times 1)}$ are the weights and offsets of the input layer, respectively, and $\omega_{2(1 \times 2)}$ and $b_{2(1 \times 1)}$ are the weights and offsets of the hidden layers, respectively. The use of BP neural network was based on experimental data by error reverse transforming and constantly updating weights and offsets to meet the fitting accuracy.

The original data is needed to be normalized according to the following equation to ensure the fitting accuracy, so that the input and output data were all between $[-1,1]$ :

$$
y=\frac{2\left(x-x_{\min }\right)}{x_{\max }-x_{\min }}-1,
$$

where $x_{\max }$ and $x_{\min }$ are the maximum and minimum values of the data to be converted, respectively, $x$ and $y$ denote the data to be converted and the converted data, respectively. Obviously, $-1 \leq y \leq 1$.

After BP neural network fitted the functional relationship that satisfied the accuracy, the calculation data were converted into the original data according to the following equation:

$$
x=\frac{\left(x_{\max }-x_{\min }\right)(y+1)}{2}+x_{\min }
$$

Combining Equations (5), (6), and (7), a more accurate $F$-s fitting equation was obtained, as shown in the following equation:

$$
F=\frac{C_{1}}{e^{-C_{2} s-C_{3}}+1}+\frac{C_{4}}{e^{-C_{5} s-C_{6}}+1}+C_{7}
$$

where $C_{1}=\left(F_{\max } \omega_{21}\right) / 2, C_{2}=2 \omega_{11} / s_{\max }, C_{3}=b_{11}-\omega_{11}$, $C_{4}=\left(F_{\max } \omega_{22}\right) / 2, \quad C_{5}=2 \omega_{12} / s_{\max } \quad C_{6}=b_{12}-\omega_{12}$, and $C_{7}=\left(F_{\max } / 2\right)\left(b_{2}+1\right)$.

Using the $F-s$ experimental data obtained through the direct shear test, $F$-s fitting equations under different normal stresses with different lime doses were obtained by means of the BP neural network algorithm. The calculation data are shown in Table 3.

The fitting curve with $4 \%$ lime is shown in Figure 7. 

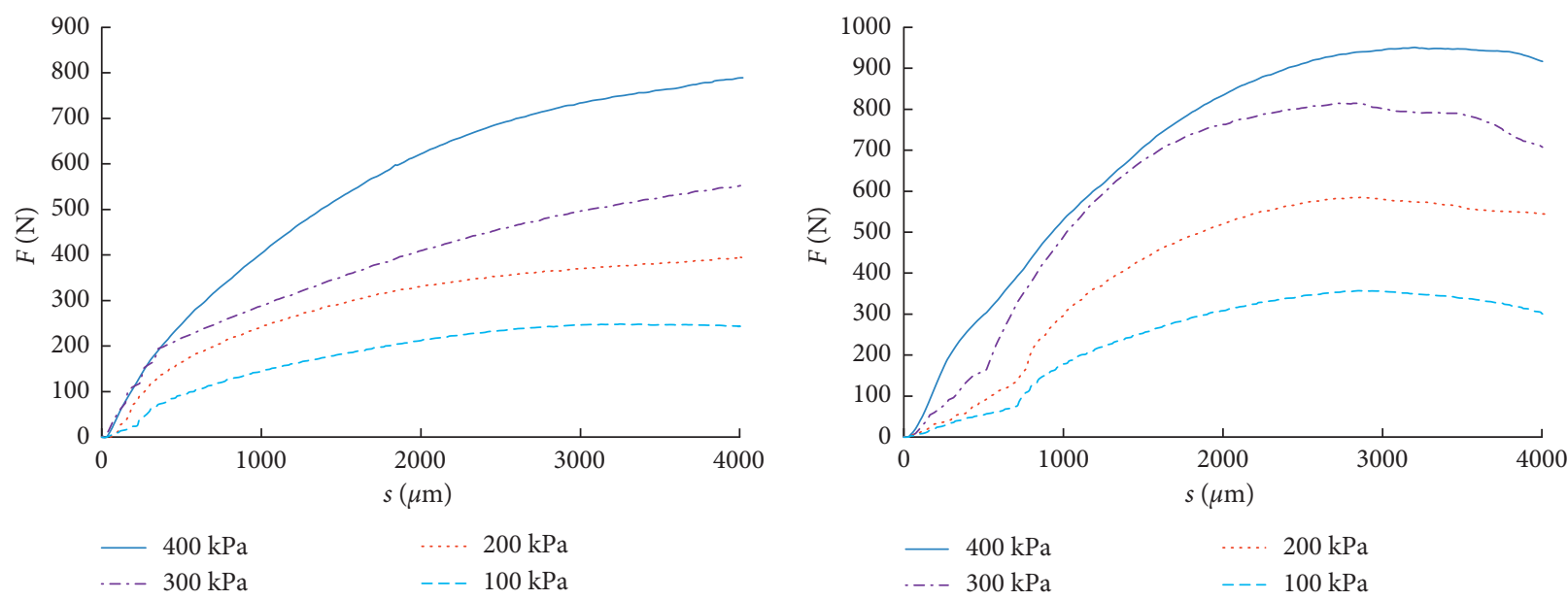

(a)

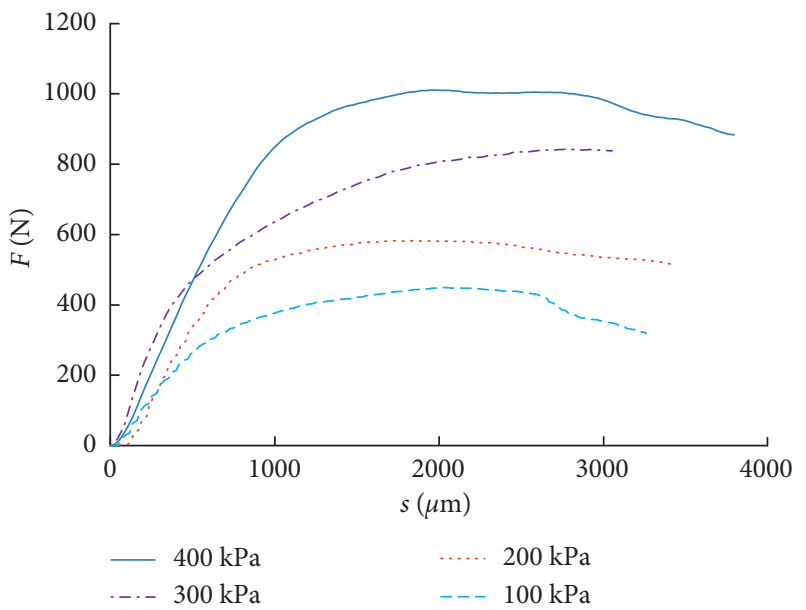

(c)

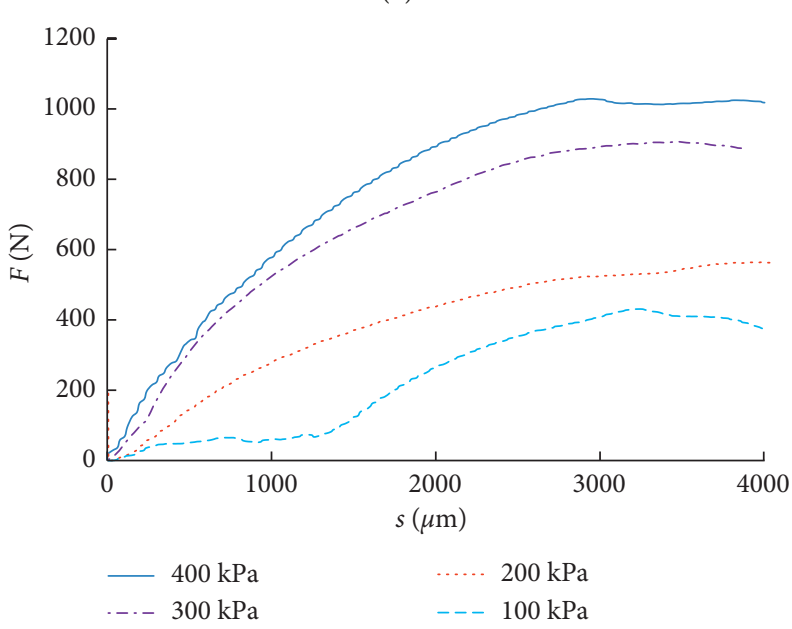

(d)

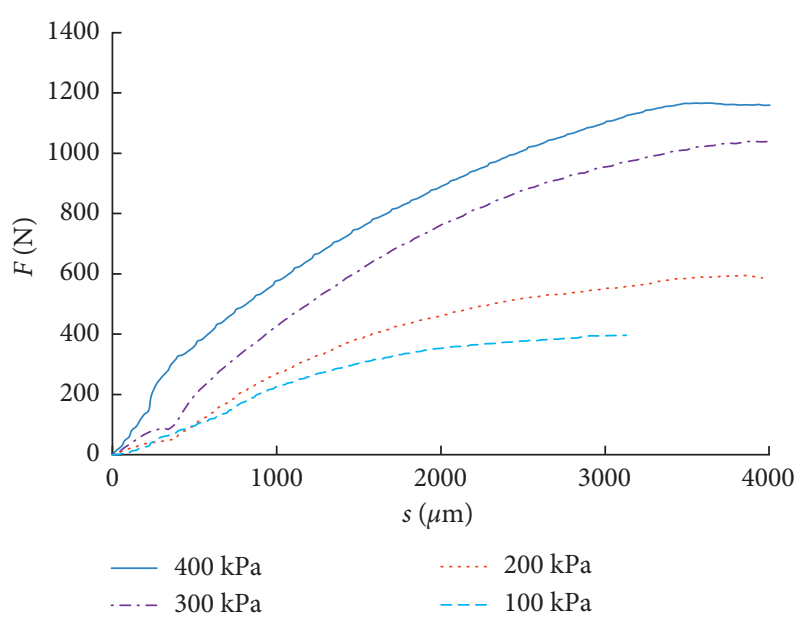

(e)

Figure 5: F-s curve of iron tailing powder with different lime doses. (a) $0 \%$ lime, (b) $2 \%$ lime, (c) $4 \%$ lime, (d) $8 \%$ lime, and (e) $10 \%$ lime.

Table 3 and Figure 7 show that the BP neural network algorithm provided a more accurate $F$-s fitting function with an average relative error less than $10 \%$. Therefore, the BP neural network algorithm was used to fit the $F-s$ function relationship.
4.2. Energy Dissipation Calculation. According to the fitting formula, the definite integral was used to obtain the shear energy dissipation of iron tailing powder with different lime doses under different normal stresses, as shown in the following equation: 


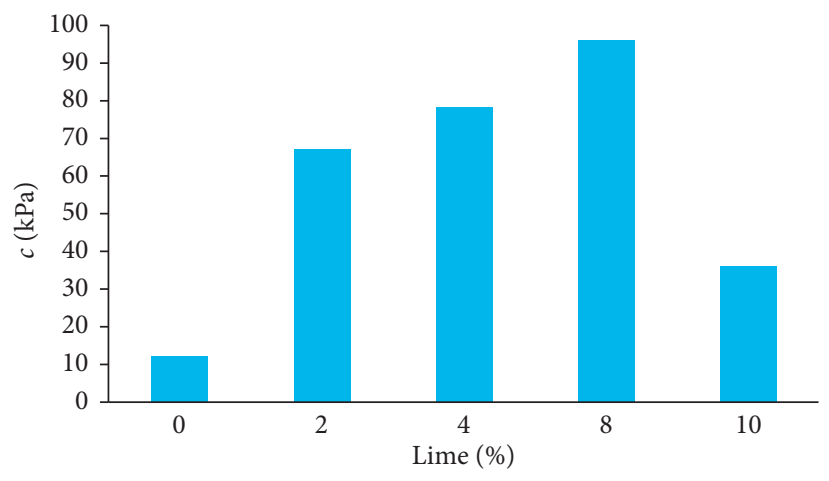

(a)

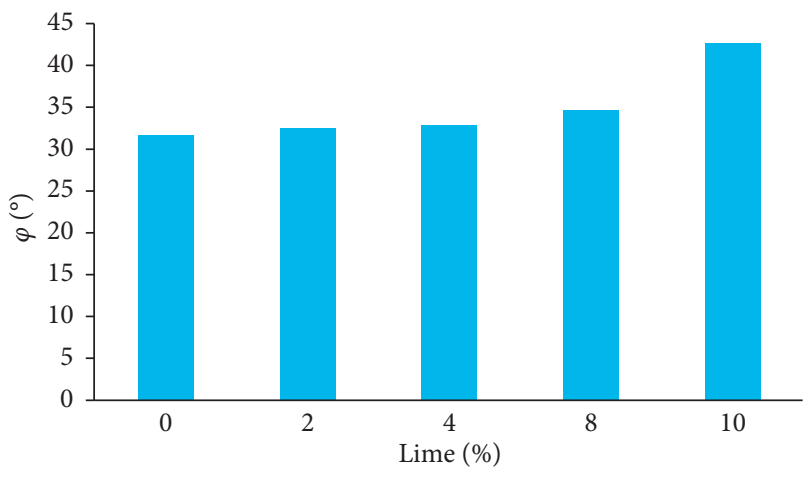

(b)

FIGURE 6: (a) Cohesion and (b) internal friction angle of iron tailing powder with different lime doses.

TABLE 3: BP neural network fitting results.

\begin{tabular}{|c|c|c|c|c|c|c|c|c|c|}
\hline Lime dosage (\%) & Normal stress $(\mathrm{kPa})$ & $C_{1}$ & $\mathrm{C}_{2}$ & $C_{3}$ & $C_{4}$ & $C_{5}$ & $C_{6}$ & $C_{7}$ & Average relative error \\
\hline \multirow{4}{*}{0} & 100 & -49.93 & 0.0023 & -9.71 & 727324 & 0.00077 & 7.87 & -727051 & 0.03 \\
\hline & 200 & -19.77 & 0.0055 & -29.97 & -4557279 & -0.00091 & -9.36 & 399 & 0.06 \\
\hline & 300 & -14.06 & 0.0033 & -17.77 & 317668 & 0.00037 & 6.33 & -317062 & 0.05 \\
\hline & 400 & 24.61 & -0.0062 & 34.9 & -38062 & -0.00067 & -3.79 & 823 & 0.02 \\
\hline \multirow{4}{*}{2} & 100 & 101.72 & -0.0041 & 16.19 & 427. & 0.002 & -1.82 & -168 & 0.06 \\
\hline & 200 & -319 & 0.0013 & -6.87 & 660 & 0.0022 & -2.31 & -64 & 0.05 \\
\hline & 300 & 143 & -0.0047 & 17.77 & -965 & -0.0024 & 1.78 & 668 & 0.02 \\
\hline & 400 & 121 & -0.0031 & 10.99 & -2121805 & -0.00077 & -7.68 & 863 & 0.05 \\
\hline \multirow{4}{*}{4} & 100 & 125 & -0.0075 & 20.69 & -2002 & -0.0021 & -1.16 & 327 & 0.02 \\
\hline & 200 & 57.6 & -0.0054 & 14.85 & 756 & 0.0044 & -1.48 & -236 & 0.12 \\
\hline & 300 & 634 & 0.0019 & -1.23 & 458 & 0.0095 & -1.54 & -240 & 0.01 \\
\hline & 400 & 152.46 & -0.0036 & 11.99 & -1363 & -0.0031 & 1.16 & 863 & 0.01 \\
\hline \multirow{4}{*}{8} & 100 & -243 & 0.0018 & -3.41 & -571 & -0.0031 & 3.48 & 581 & 0.09 \\
\hline & 200 & -537 & -0.0013 & 1.41 & -134 & -0.0067 & 3.18 & 572 & 0.08 \\
\hline & 300 & -70.42 & 0.0055 & -19.89 & 331411 & 0.00075 & 5.78 & -330411 & 0.03 \\
\hline & 400 & -1162 & 0.00088 & -3.73 & 89179 & 0.0003 & 3.69 & -86966 & 0.06 \\
\hline \multirow{4}{*}{10} & 100 & 587 & 0.0015 & -0.68 & -24.39 & -0.023 & 17.96 & -181 & 0.03 \\
\hline & 200 & 533 & 0.0012 & -1.5 & 183 & 0.0046 & -3.28 & -103 & 0.04 \\
\hline & 300 & -1350 & -0.0011 & 1.06 & -86.05 & -0.013 & 7.37 & 1086 & 0.03 \\
\hline & 400 & -356 & -0.0023 & 6.55 & -942 & -0.002 & 1.91 & 1173 & 0.03 \\
\hline
\end{tabular}

$$
W=\int_{0}^{s_{\max }} F(s) d s
$$

where $s_{\max }$ is taken as $4 \mathrm{~mm}$ consistent with the provisions of 4.7 in Test Method of Soils for Highway Engineering (JTG E40-2007) [23]. The calculation results of the shear energy dissipation of iron tailing powder with different lime doses under different normal stresses are shown in Table 4.

Figure 8 shows that the shear energy dissipation of iron tailing powder with different lime doses increased linearly with increasing normal stress. The shear energy dissipation of lime-reinforced iron tailing powder was higher than that of normal iron tailing powder, and the iron tailing powder with $4 \%$ lime had the largest energy dissipation value.

Figure 9 shows that under different normal stresses, the shear energy dissipation of lime-reinforced iron tailing powder had the same variation tendency with increasing

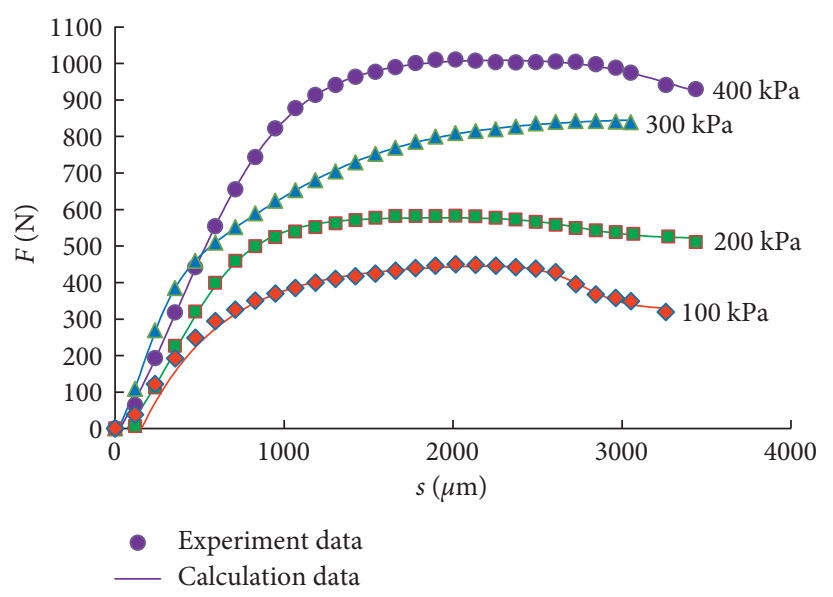

Figure 7: F-s fitting curve of iron tailing powder with $4 \%$ lime. 
TABLE 4: Shear energy dissipation of iron tailing powder with different lime doses under different normal stresses $(J)$.

\begin{tabular}{lcccc}
\hline \multirow{2}{*}{ Lime (\%) } & \multicolumn{4}{c}{ Normal stress $(\mathrm{kPa})$} \\
& 100 & 200 & 300 & 400 \\
\hline 0 & 0.74 & 1.18 & 1.24 & 2.2 \\
2 & 0.99 & 1.62 & 2.44 & 2.67 \\
4 & 1.4 & 1.95 & 2.82 & 3.33 \\
8 & 1.18 & 1.54 & 2.68 & 2.39 \\
10 & 1.18 & 1.1 & 2.68 & 2.71 \\
\hline
\end{tabular}

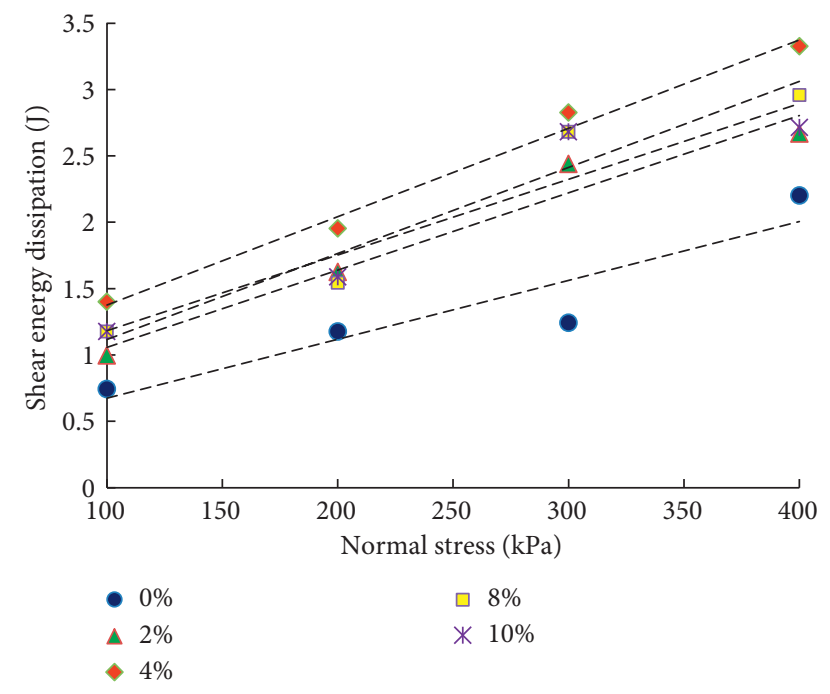

FIGURE 8: Shear energy dissipation of lime-reinforced iron tailing powder under different normal stresses.

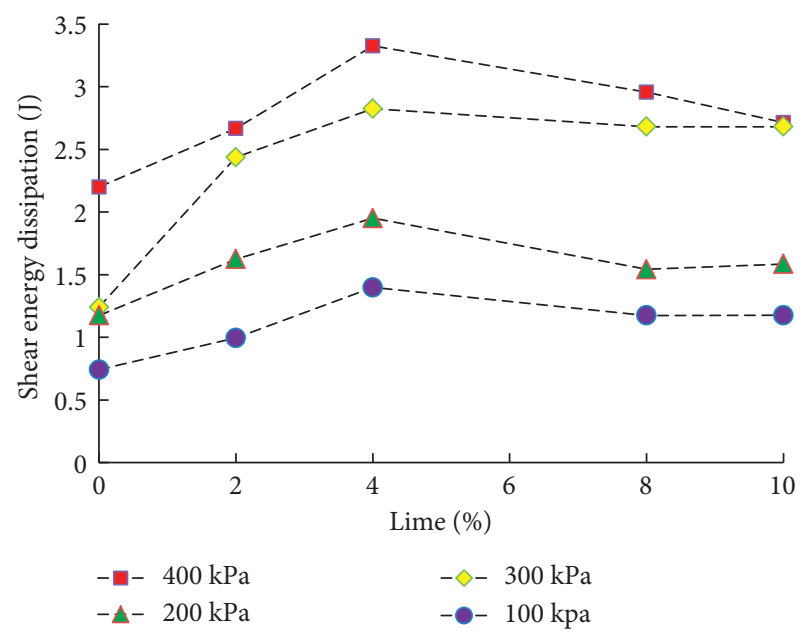

Figure 9: Shear energy dissipation of lime-reinforced iron tailing powder with different lime doses.

lime dose. That is, the shear energy dissipation first increased and then decreased gradually with increasing lime dose. When the lime dosage was $4 \%$, the shear energy dissipation value was the largest. Therefore, it was concluded that $4 \%$ lime provided the best ratio.

\section{Conclusions}

This study proposed a method for using lime to strengthen iron tailing powder based on the research findings on the lime soil. The $F-s$ curves and $c$ and $\varphi$ values of iron tailing powders with $0 \%, 2 \%, 4 \%, 8 \%$, and $10 \%$ lime content were obtained through direct shear tests. The BP neural network algorithm was used to fit the $F-s$ curve. Based on the energy dissipation theory, the shear failure energy dissipation of iron tailing powder with different lime doses under different normal stresses of $100 \mathrm{kPa}, 200 \mathrm{kPa}, 300 \mathrm{kPa}$, and $400 \mathrm{kPa}$ was achieved in the form of a definite integral. Several conclusions are drawn as follows:

(1) BP neural network algorithm has a good fitting accuracy and can be used to fit the F-s curve in the direct shear test.

(2) The cohesion of lime-reinforced iron tailing powder first increases and then decreases with increasing lime dose. Also, the internal friction angle increases with increasing lime dose.

(3) The incorporation of lime can increase the shear energy dissipation of iron tailing powder. With the increase in lime dose, the shear energy dissipation of iron tailing powder first increases and then decreases, reaching the maximum with $4 \%$ lime. Furthermore, the energy dissipation increases linearly with increasing normal stress.

\section{Data Availability}

All the data used to support the findings of this study are included within the article.

\section{Conflicts of Interest}

The authors declare that they have no conflicts of interest.

\section{Acknowledgments}

This work was supported by the National Natural Science Foundation of China (41772311 and 51579199), Zhejiang Provincial Natural Science Foundation of China (LY17E080016), and the Research Fund of Zhejiang Provincial Department of Housing and Urban-Rural Development (2017K179, 2016K130).

\section{References}

[1] F. H. Han, L. Li, S. M. Song, and J. Liu, "Early-age hydration characteristics of composite binder containing iron tailing powder," Powder Technology, vol. 315, pp. 322-331, 2017.

[2] P. Duan, C. Yan, W. Zhou, and D. Ren, "Development of fly ash and iron ore tailing based porous geopolymer for removal of $\mathrm{Cu}(\mathrm{II})$ from wastewater," Ceramics International, vol. 42, no. 12, pp. 13507-13518, 2016.

[3] M. A. Onitiriand and E. T. Akinlabi, "Effects of particle size and particle loading on the tensile properties of iron-ore-tailingfilled epoxy and polypropylene composites," Mechanics of Composite Materials, vol. 52, no. 6, pp. 817-828, 2017. 
[4] L. Panda, S. K. Biswal, R. Venugopaland, and N. R. Mandre, "Recovery of ultra-fine iron ore from iron ore tailings," Transactions of the Indian Institute of Metals, vol. 71, no. 2, pp. 463-468, 2018.

[5] L. A. D. C. Bastos, G. C. Silva, J. C. Mendes, and R. A. F. Peixoto, "Using iron ore tailings from tailing dams as road material," Journal of Materials in Civil Engineering, vol. 28, no. 10, article 04016102, 2016.

[6] N. C. Consoli, L. Da Silva Lopes Jr, B. S. Consoli, and L. Festugato, "Mohr-Coulomb failure envelopes of limetreated soils," Géotechnique, vol. 64, no. 2, pp. 165-170, 2014.

[7] Y. Wang, M. Duc, Y. J. Cui et al., "Aggregate size effect on the development of cementitious compounds in a lime-treated soil during curing," Applied Clay Science, vol. 136, pp. 58-66, 2017.

[8] Y. Wang, Y. J. Cui, A. M. Tang, C. S. Tang, and N. Benahmed, "Changes in thermal conductivity, suction and microstructure of a compacted lime-treated silty soil during curing," Engineering Geology, vol. 202, pp. 114-121, 2016.

[9] Y. Wang, Y. J. Cui, A. M. Tang, N. Benahmed, and M. Duc, "Effects of aggregate size on the compressibility and air permeability of lime-treated fine-grained soil," Engineering Geology, vol. 228, pp. 167-172, 2017.

[10] A. K. Jhaand and P. V. Sivapullaiah, "Volume change behavior of lime treated gypseous soil -influence of mineralogy and microstructure," Applied Clay Science, vol. 119, pp. 202-212, 2016.

[11] A. K. Jhaand and P. V. Sivapullaiah, "Physical and strength development in lime treated gypseous soil with fly ash-microanalyses," Applied Clay Science, vol. 145, no. 1, pp. 17-27, 2017.

[12] E. Vitale, D. Deneele, G. Russoand, and G. Ouvrard, "Shortterm effects on physical properties of lime treated kaolin," Applied Clay Science, vol. 132-133, pp. 223-231, 2016.

[13] X. L. Yang and Z. W. Li, "Factor of safety of three-dimensional stepped slopes," International Journal of Geomechanics, vol. 18, no. 6, article 04018036, 2018.

[14] Z. G. Zhang, Y. Q. Chen, and Z. P. Huang, "A novel constitutive model for geomaterials in hyperplasticity," Computers and Geotechnics, vol. 98, pp. 102-113, 2018.

[15] S. Nadimi and J. Fonseca, "A micro finite-element model for soil behavior: numerical validation," Géotechnique, vol. 68, no. 4, pp. 364-369, 2018.

[16] K. Tamas, "The role of bond and damping in the discrete element model of soil-sweep interaction," Biosystems Engneering, vol. 169, pp. 57-70, 2018.

[17] K. J. Hanley, X. Huang, and C. Q'Sullivan, "Energy dissipation in soil samples during drained triaxial shearing," Géotechnique, vol. 68, no. 5, pp. 421-433, 2018.

[18] Z. W. Zhou, W. Ma, S. J. Zhang, Y. H. Mu, and G. Y. Li, "Effect of freeze-thaw cycles in mechanical behaviors of frozen loess," Cold Regions Science and Technology, vol. 146, pp. 9-18, 2017.

[19] W. Wang, N. Li, F. Zhang, A. Zhou, and S. Chi, "Experimental and mathematical investigations on unconfined compressive behavior of coastal soft soil under complicated freezing processes," Polish Maritime Research, vol. 23, no. 4, pp. 112-116, 2016.

[20] Y. Liu, Y. Jiang, H. Xiao, and F. H. Lee, "Determination of representative strength of deep cement-mixed clay from core strength data," Géotechnique, vol. 67, no. 4, pp. 350-364, 2017.

[21] F. He and L. Zhang, "Prediction model of end-point phosphorus content in BOF steelmaking process based on PCA and BP neural network," Journal of Process Control, vol. 66, pp. 51-58, 2018.

[22] X. Yu, J. Han, L. Shi, Y. Wang, and Y. Zhao, “Application of a BP neural network in predicting destroyed floor depth caused by underground pressure," Environmental Earth Sciences, vol. 76, no. 15, p. 535, 2017.

[23] Profession Standard Of The People's Republic Of China, Test Method of Soils for Highway Engineering (JTG E40-2007), People's Communications Press, Beijing, China, 2007. 


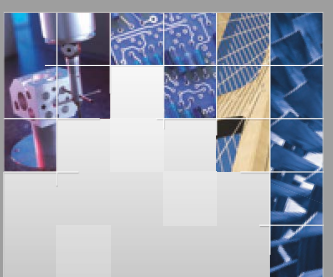

\section{Enfincering}
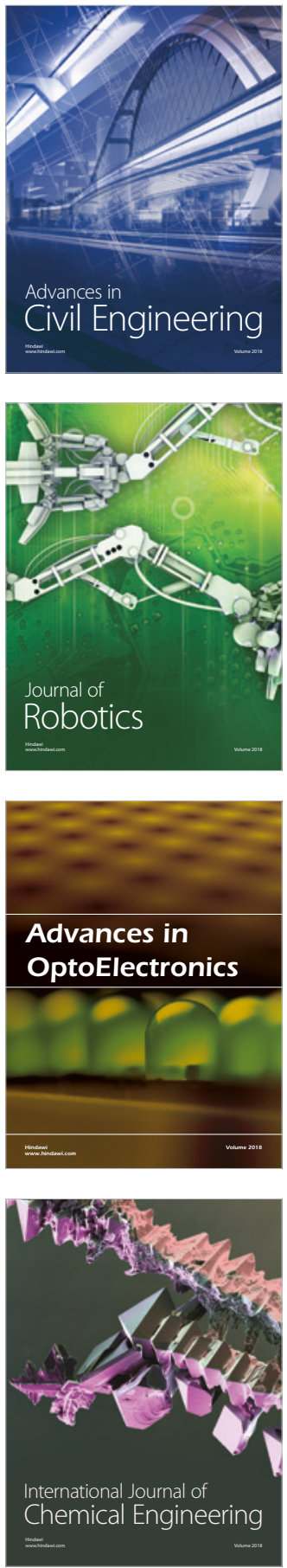

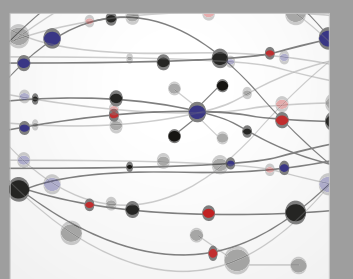

\section{Rotating \\ Machinery}

The Scientific World Journal

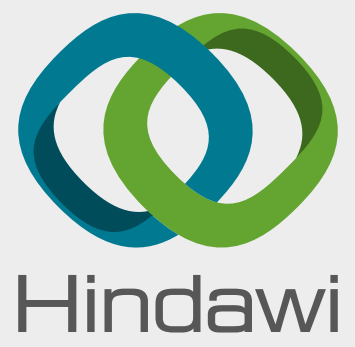

Submit your manuscripts at

www.hindawi.com
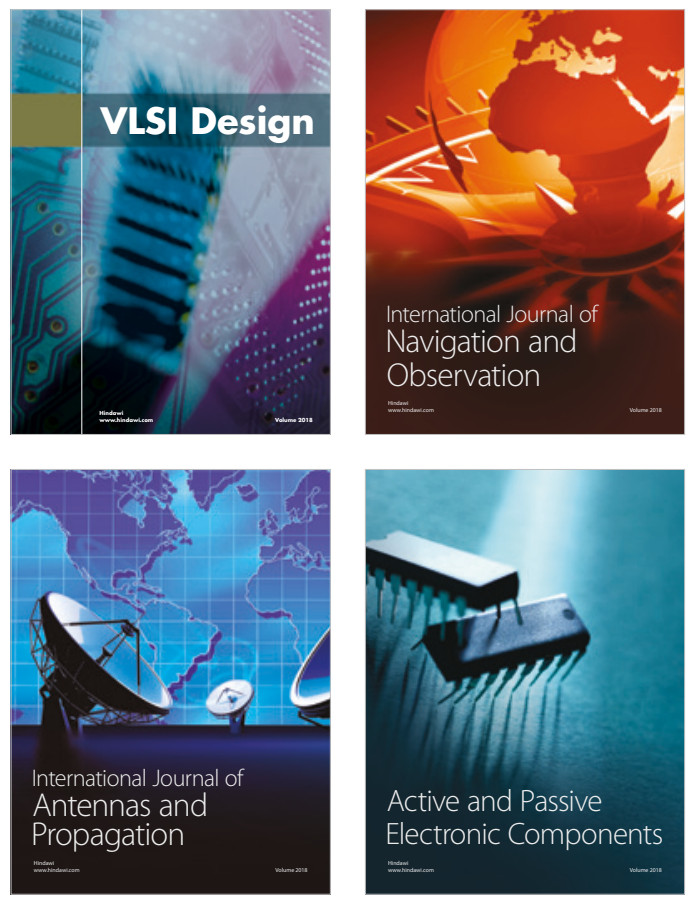
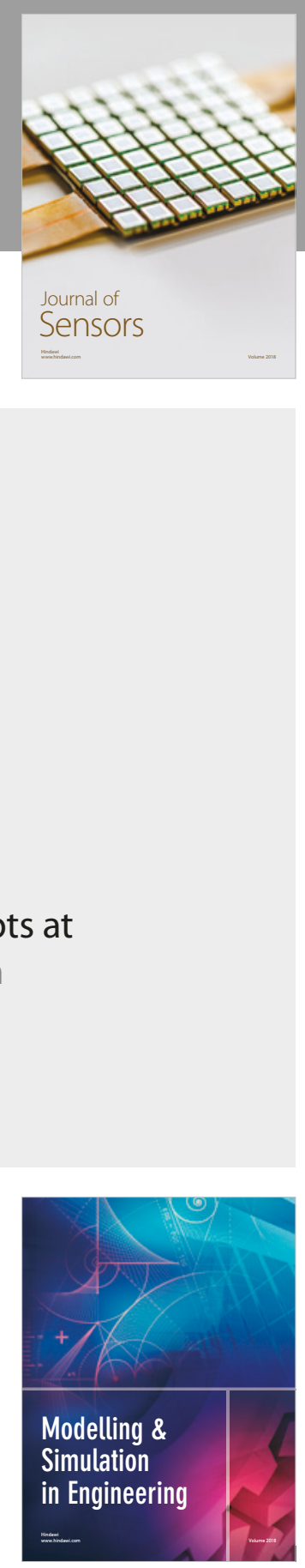

\section{Advances \\ Multimedia}
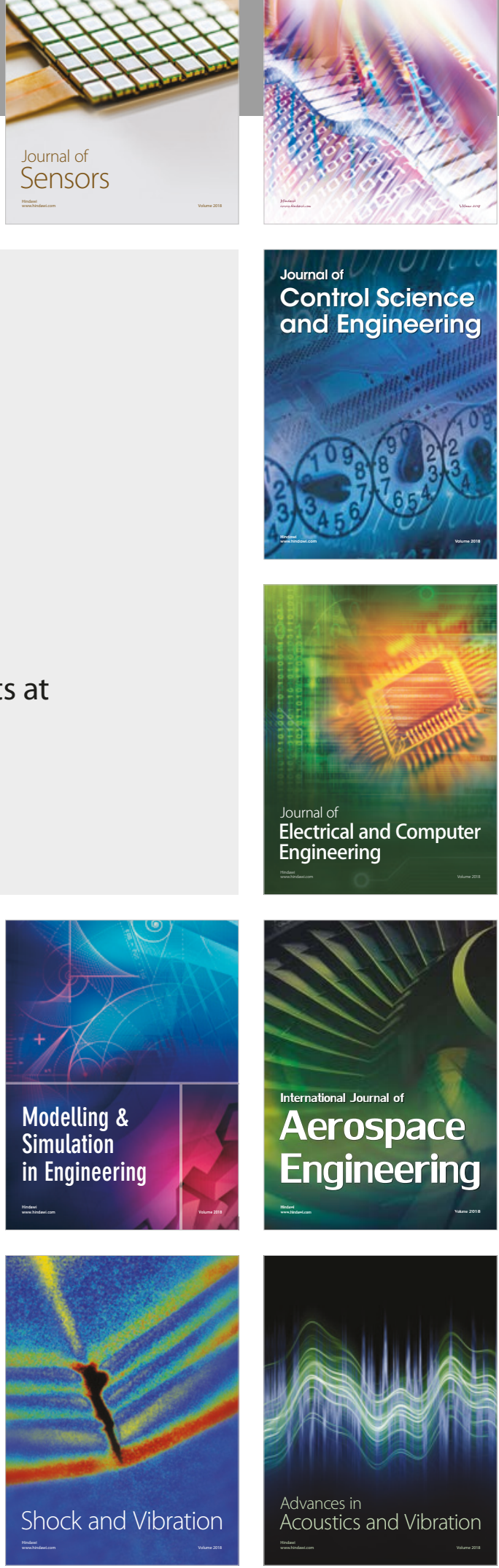